\title{
The Perception of Mobile Banking Adoption: The Study of Behavioral, Security, and Trust in Thailand
}

\author{
Chat Chuchuen
}

\begin{abstract}
Mobile technology plays important role in various daily activities. Banking transaction is one of a transaction process which is transformed by information technology. Mobile banking (M-banking) has a dramatically growth rate according to the increasing number of mobile device users. However, there are many factors that relate in M-banking adoption process. This paper demonstrates a conceptual model and propositions for identifying Thai adopter factors of M-banking adoption for improving the M-banking adoption process especially in term of M-banking providers. Specifically, this explains and examines the relationship samong behavioral factors, perceived ease of use (PEOU), perceived of usefulness (PU), security factors, and trust factors, M-banking adoption, and M-banking Intention. Suggestions for future research and empirical testing of propositions are offered.
\end{abstract}

Index Terms-M-banking, TPB, TAM, trust, security.

\section{INTRODUCTION}

Information Technology (IT) innovation has affected on many daily activities. Banking transaction is another activity that comes to play and quite significant for the daily living. Changes from applying technology in many ways have shifted the form of traditional banking transactions to mobile banking (M-banking) that emphasizes on the more convenience of customer usage [1]. M-banking is the transaction that brings technological advantages to apply with diverse functions for example, authentication, authorization, etc. Moreover, the amount of M-banking user has expanded dramatically in every year and in many countries for example in USA, Europe, and Asia [2]. Thus, various factors might affect the M-banking adoption such as unprompted on technology Infrastructure, user behavioral, security, and customer trust.

The Third generation communication technology (3G) is implemented in various countries included Thailand. Consequently with BOT survey in 2014demonstrates that there is an increasing growth of Thai M-banking transaction rate totaled 57,199 thousand transactions in 2013 which a 57.64 percent increase from 2012.Moreover, the fourth generation era of communication technology (4G) is under the development and implementation phase in some countries. As the mobile commerce increases in popularity, mobile banking continues to facilitate secure electronic commercial transactions between organizations and individuals [3], [4].A change from the former transaction and payment took place when the Internet was introduced to the users who wanted to

Manuscript received January 9, 2014; revised March 15, 2015.

Chat Chuchuen is with the Faculty of Business Administration, Maejo University, Chiang Mai, 50290, Thailand (e-mail: chat@mju.ac.th). pay via websites whose vendors were receivers, banks, or financial institutions, whenever and wherever they wished to. Since, it was mainly completed in a personal computer or a laptop, a prime concern was on safety caution against fraud. Since 2011, the world has obviously paced into the mobile device era. Sales of mobile devices such as smartphones and tablets have constantly increased for many years. Even though, the technology infrastructure limitations seem to be decreased; but there are other factors that M-banking service providers should concentrate for their service process improvement. Not only the factors that will relate in M-banking adoption process, but also user behavior, security, and trust that largely explored in many researches [5], [6]. Thus, the user behavioral, perceived in usage, security, and trust in innovation is focused in this study.

Due to, there are many limitations in innovation adoption process, Hence, this study will explore in this following question;

What are the influencing factors in M-banking adoption in Thailand?

The objectives study of Thailand Mobile Banking Adoption: The study of Behavioral, Security and Trust which due to the problem statement above are stated as the following:

1) To identify relevant factors that influence in M-banking adoption in Thailand.

2) To determine the relationships among relevant factors in M-banking adoption, and M-banking intention.

\section{LiteratURE REVIEW}

\section{A. Mobile Banking (M-Banking)}

There is more freedom for the majority of banking services emulated M-banking as the bank uses mobile phones to perform on most of banking activities. The former studies presented so many adopted M-banking definitions. M-banking is a mobile payment and commerce application that allows the clients with virtual convenient banking at any time and place [7]. This is termed as the banking provision and financial services in associated for instance, mobile devices money transferring, bank saving and stock exchange transactions [6]. Variety of financial functions are provided from M-banking services such as merchants commercial payments, utilities bill-payments, person to person (P2P) transfers, business to person (B2P) transfers, business to business (B2B) transfers, and long-distance remittances [8]. M-banking according to Donner et al., [9] is termed as "collectively to the applications set that allow people to use mobile phones in their bank accounts manipulation and store the account value in connection with their handsets, access to 
credit and insurance products or funds transfer." M-banking is defined by mobile phone providers as the potential service that offer for customers to boost their loyalty while charging for messaging and generating fees [10]. Financial institutions with the difficult time to offer the profitable services to poor client via traditional channels see M-banking as the 'branchless banking form.' While according to [11] this can lower the low-income customers serving costs. Many of M-banking transactions and service provider from many nations in particular Thailand that keeps progressing every year. The value and volume of Thailand M-banking transaction will be demonstrated in the table below.

TABLE I: THE VOLUME AND VALUE OF M-BANKING TRANSACTION IN THAILAND BETWEEN 2010 TO 2013

\begin{tabular}{ccrrr}
\hline \hline & 2013 & 2012 & 2011 & 2010 \\
\hline Volume of Transaction (Thousand & 57,19 & 36,28 & 19,94 & 15,88 \\
transactions) & 9 & 5 & 2 & 5 \\
Value of Transaction (Billions of & 752 & 440 & 187 & 110 \\
Baht) & & & & \\
\hline \hline Source: "Use of mobile banking" bank of Thailand, 2014. &
\end{tabular}

We can classify M-banking into three types [5] namely: 1) Wireless Application Protocol (WAP) M-banking. 2) SMS/text alerts M-banking. 3) Unstructured Supplementary Service Data (USSD) M-banking.In this study, the author defined M-banking as the operation of payment initiating by mobile device to allow and confirmfor the banking transaction [3], [7], [9].

\section{B. Theory of Plan Behavior}

Starting from Theory of Reasoned Action in 1980, Theory of Planned Behavior (TPB) used to forecast the intention of individual to make the behavioral engagement on particular place and time frame [12]. The intent of this theory is to describe total of behaviors that person can exert their self-control [13]. This model has the key component as the behavioral intent since it can be influenced via the potential attitude and the expected outcome can result from the behavior and the subjective risk and benefits evaluation from that consequence [13].

\section{Technology Acceptance Model}

TAM refers to Theory of Reasoned Action (TRA) adapting to IS field. It is posited by TAM that the perceived on ease of use and perceived usefulness can reflect the intention of person to adopt the system with adopting intention that serve as the actual system use mediator [14], [15]. The author presented the original TAM in regard of two key system determinants which are the perceived usefulness (PU) and perceived ease of use (PEOU). The attitude toward using (ATU) in this model can directly forecast the behavioral intention of users by using $(\mathrm{BI})$ to determine the real system use (AU). It is suggested from various researchers that it requires TAM to include more variables to strengthen the model [16], [17].

\section{Conceptual Model AND the Propositions}

From the literature review, the variable from Theory of Planned and Behavior (TPB),Technology Acceptance Model
(TAM), perceived of customer trust, and perceived of security should be tested among intention in M-banking adoption in Thailand, and their actual M-banking adoption [5], [15], [18]. Hence, the research conceptual framework is presented as follows;

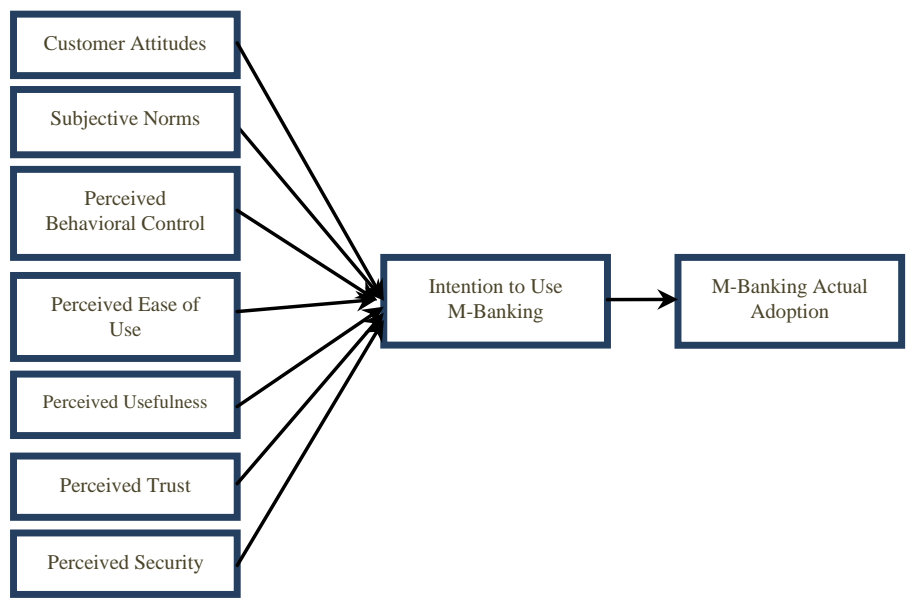

Fig. 1. The research conceptual Model.

\section{A. Customer Attitudes, Subjective Norm, Perceived Behavioral Control}

The TPB has been successfully used to predict and explain a wide range of health behaviors and intentions including smoking, drinking, health services utilization, breastfeeding, and substance used among others [18]. The TPB states that behavioral achievement depends on both motivation (intention) and ability (behavioral control) [12], [13]. It distinguishes between three types of beliefs - behavioral, normative, and control as follow.

1) Customer attitude refers to the degree to which a person has a favorable or unfavorable evaluation of the behavior of interest. It entails a consideration of the outcomes from the behavioral performance [13], [18].

2) Subjective norms refer to the belief on whether most of people approve or disapprove of the behaviors. It relates to a person's beliefs about whether peers and people of importance to them think that he or she should engage in the behavior [13], [18].

3) Perceived behavioral control refers to a person's perception on the ease or difficulty in behavior of interest performance. Perceived behavioral control can be varied across situations and actions, which results in a person having different perceptions of behavioral control depending on the situation. This construct of the theory was added later, and created the shift from the Theory of Reasoned Action (TRA) into the Theory of Planned Behavior (TPB) [13], [18].

Therefore, previous studies lead to the following propositions;

P1: Customer attitudes will be positively related to an intention to use M-banking.

P2: Subjective norm will be positively related to an intention to use M-banking.

P3: Perceived behavioral control will be positively related to an intention to use M-banking. 


\section{B. Perceived Ease of Use (PEOU) and Perceived Usefulness (PU)}

Perceived usefulness (PU) is also seen with the direct impact from the perceived on ease of use. Researchers have simplified TAM by removing the attitude construct found in TRA from the current specification [19]. The attempts to extend TAM have generally taken one among the three approaches: by introducing factors from related models, by introducing additional or alternative belief factors, and by examining antecedents and moderators of perceived usefulness (PU) and perceived ease of use (PEOU) [20]. In this study, perceived usefulness (PU) refers to the tendency that customer will use or will not use M-banking system from the extent that they believe it will help them process their task well [19]. And Perceived ease of use (PEOU) refers to the degree to which a person believes that online transactions engaging via M-banking would be free of effort [21]. A system that is easy to use will easily accomplish tasks compared to the more difficult system [17]. Thus, from above studies, they lead to the following propositions:

P4: The perceived ease of use in M-banking will be positively related to an intention to use M-banking.

P5: The perceived usefulness in M-banking will be positively related to an intention to use M-banking.

\section{Perceived Trust in M-banking}

The services such as financial transactions from one account to another account, loans, and retail sales are the services provided by M-banking and M-payment [22]. Clients can obtain the balance related information via their mobile devices in form of SMS. There are 4G LTE, 3G and EDGE that allow clients to access a large service range such as financial transferring from one to another account, stock trading, and M-payment for items purchasing done via mobile devices. As such, M-banking and M-payment seem to gain more popularity in Europe, while in the United States, due to the absence of clients' trust on M-banking, then banks have closed these services. The key factors for M-commerce, M-banking, and M-payment advancement are for convenience and security [3]. Trust in M-banking is seen as the top crucial factor for the reason that the financial transactions have to be done online without face-to-face contact. Trustworthiness also means the confidence on a business partner that can convince that the partner will conform to the business rules [23]. Technologies acceptance and willingness to transfer money has depended on customer trust. Customers have less trust on M-banking and M-payment due to some issues related to M-banking and M-payment adoption cost, security, and convenience in the process. This leads to the proposition 6 :

P6: The perceived trust in M-banking usage will be positively related to an intention to use M-banking.

\section{Perceived Security}

For M-banking, the security issue is a source of concern among users while so far numerous solutions and systems have been presented in order to increase M-banking security
[22], [24]. The security problems and issues would be based on various M-banking technologies. In network banking, the problems of information security are for instance hackers, virus attacks, etc. which can take place in M-banking system operation as well. Hence, the proposition is:

P7: The perceived security in M-banking usage will be positively related to an intention to use M-banking.

\section{E. Intention to Use M-banking}

Studies have pointed out that the level of trust in a firm affects customers' intention to make use of its services or products [25], [26]. Jarvenpaa \& Tractinsky [27] showed that customers' confidence in an internet shopping mall affected their intention to purchase. McKnight et al. [28], [29] depicted a close association between trusting beliefs and trusting intentions. Kim \&Prabhakar [30] demonstrated that a consumer's willingness to take part in online banking is contingent on his/her level of trust. According to Suh \& Han [24], trust mediates the relationship between a person's perception of security control and his/her acceptance of online banking. In their qualitative study, Rotchanakitumnuai \& Speec e[31] found that the limited success of internet banking in Thailand was resulted from the lack of people trust on the service providers. Additionally, several studies that examined on internet shopping services demonstrated a link between trust in Web stores and customers' usage or usage intentions [32]. Intention To Use (ITU) M-banking refers to the user's likelihood to use online transactions through M-banking [33], [34]. Thus, the proposition is:

P8: Intention to Use M-banking will be positively related to the actual adoption of M-banking.

\section{CONCLUSION AND DisCUSSION}

According to conceptual framework model, four important factors related to the M-banking customers are affected on the intention and adoption of M-banking. From the first variables in testing, which is customer behavior factor in M-banking usage, any customer who has good attitudes, subjective norms or high interesting in using mobile application or E-banking should have higher intentions on M-banking operation. For the second variable, perceived ease of use and perceived usefulness in M-banking usage, the customer who gain benefits and high familiarity in mobile application or E-banking will have higher intentions in M-banking usage. Thirdly, the perceived of customer trust in M-Banking adoption explains that when a customer feels that he or she can perceive more trust and high secure in M-banking functions, the customer will have higher intentions toward M-banking adoption. Finally, the relationship between M-banking intention and M-banking adoption which refers to satisfaction showed that any customers have high expectations toward M-banking, thus service providers should provide their M- banking services at their expected level in order to increase the level of customer satisfaction. 


\section{FUtURE STUdY AND LIMITATION}

The opportunities for future research for this paper should continue the empirical research to test the proposition with the sample that can show the related direction of the proposition. The other, to consider in some variable factors that can be adopted for future studies for test the other dimensions and the study should be able to replicate the process in other type of mobile application such as M-payment, M-commerce etc. Finally, we encourage this research work will be more beneficial if it is expanded in the future to test the relationships in our suggested model by using the empirical data or other techniques.

\section{REFERENCE}

[1] R.-A. Shang, Y.-C. Chen, and L. Shen, "Extrinsic versus intrinsic motivations for consumers to shop on-line," Information and Management, vol. 42, pp. 401-413, 2005.

[2] T. Laukkanen, "Internet vs mobile banking: Comparing customer value perceptions," Business Process Management Journal, vol. 13, pp. 788-797, 2007.

[3] N. Mallat, M. Rossi, and V. K. Tuunainen, "Mobile banking services," Communications of the ACM, vol. 47, pp. 42-46, 2004.

[4] J. Ondrus and Y. Pigneur, "Towards a holistic analysis of mobile payments: A multiple perspectives approach," Electronic Commerce Research and Applications, vol. 5, pp. 246-257, 2006.

[5] A. AlSoufi and H. Ali, "Customers perception of mbanking adoption in of Bahrain: an empirical assessment of an extended tam model," arXiv preprint arXiv: 1403.2828, 2014.

[6] R. Tiwari, S. Buse, and C. Herstatt, "Mobile services in banking sector: the role of innovative business solutions in generating competitive advantage," Technology and Innovation Managment Working Paper, 2007.

[7] M. Suoranta, Adoption of Mobile Banking in Finland, Jyväskylän yliopisto, 2003.

[8] S. K. Chitungo and S. Munongo, "Extending the technology acceptance model to mobile banking adoption in rural Zimbabwe," Journal of Business Administration and Education, vol. 3, 2013.

[9] J. Donner and C. A. Tellez, "Mobile banking and economic development: Linking adoption, impact, and use," Asian Journal of Communication, vol. 18, pp. 318-332, 2008.

[10] N. Wishart, Micro-Payment Systems and Their Application to Mobile Networks: Examples of Mobile-enabled Financial Services, Philippines: Infodev, 2006.

[11] G. Ivatury and I. Mas, "The early experience with branchless banking," Focus Note, vol. 46, 2008

[12] M. Suoranta and M. Mattila, "Mobile banking and consumer behaviour: new insights into the diffusion pattern," Journal of Financial Services Marketing, vol. 8, pp. 354-366, 2004

[13] C. F. Yemen, "Determinants of behavioral intention to mobile banking," Expert Systems with Applications, vol. 36, no. 9, 2009.

[14] F. D. Davis, R. P. Bagozzi, and P. R. Warshaw, "User acceptance of computer technology: A comparison of two theoretical models," Management Science, vol. 35, pp. 982-1003, 1989.

[15] W. J. Doll, A. Hendrickson, and X. Deng, "Using Davis's perceived usefulness and ease - of - use instruments for decision making: A confirmatory and multigroup invariance analysis," Decision Sciences, vol. 29, pp. 839-869, 1998.

[16] P. Legris, J. Ingham, and P. Collerette, "Why do people use information technology? A critical review of the technology acceptance model," Information and management, vol. 40, pp. 191-204, 2003.

[17] J.-H. Wu and S.-C. Wang, "What drives mobile commerce?: An empirical evaluation of the revised technology acceptance model," Information and management, vol. 42, pp. 719-729, 2005.

[18] J.-C. Gu, S.-C. Lee, and Y.-H. Suh, "Determinants of behavioral intention to mobile banking," Expert Systems with Applications, vol. 36 , pp. 11605-11616, 2009.
[19] V. Venkatesh, M. G. Morris, G. B. Davis, and F. D. Davis, "User acceptance of information technology: Toward a unified view," MIS Quarterly, pp. 425-478, 2003.

[20] B. H. Wixom and P. A. Todd, "A theoretical integration of user satisfaction and technology acceptance," Information Systems Research, vol. 16, pp. 85-102, 2005.

[21] L.-D. Chen, M. L. Gillenson, and D. L. Sherrell, "Enticing online consumers: An extended technology acceptance perspective," Information and management, vol. 39, pp. 705-719, 2002.

[22] S. Bhosale and B. Sawant, "Biometric security in mobile banking," International Journal of Research in Computer Application and Management, vol. 2, 2012.

[23] I. Benbasat and W. Wang, "Trust in and adoption of online recommendation agents," Journal of the Association for Information Systems, vol. 6, pp. 4, 2005.

[24] B. Suh and I. Han, "The impact of customer trust and perception of security control on the acceptance of electronic commerce," International journal of electronic commerce, vol. 7, pp. 135-161, 2003.

[25] D. Gefen and D. W. Straub, "Consumer trust in B2C e-commerce and the importance of social presence: Experiments in e-products and e-services," Omega, vol. 32, pp. 407-424, 2004.

[26] P. A. Pavlou and D. Gefen, "Building effective online marketplaces with institution-based trust," Information Systems Research, vol. 15, pp. $37-59,2004$

[27] S. L. Jarvenpaa, N. Tractinsky, and L. Saarinen, "Consumer trust in an internet store: a cross - cultural validation," Journal of Computer Mediated Communication, vol. 5, pp. 0-0, 1999

[28] D. H. McKnight, V. Choudhury, and C. Kacmar, "The impact of initial consumer trust on intentions to transact with a web site: A trust building model," The Journal of Strategic Information Systems, vol. 11, pp. 297-323, 2002.

[29] D. H. McKnight, V. Choudhury, and C. Kacmar, "Developing and validating trust measures for e-commerce: An integrative typology," Information Systems Research, vol. 13, pp. 334-359, 2002.

[30] K. K. Kim and B. Prabhakar, "Initial trust and the adoption of B2C e-commerce: The case of internet banking," ACM Sigmis Database, vol. 35, pp. 50-64, 2004.

[31] S. Rotchanakitumnuai and M. Speece, "Barriers to internet banking adoption: A qualitative study among corporate customers in Thailand," International Journal of Bank Marketing, vol. 21, pp. 312-323, 2003.

[32] C. Liu, J. T. Marchewka, J. Lu, and C.-S. Yu, "Beyond concern: a privacy-trust-behavioral intention model of electronic commerce," Information and Management, vol. 42, pp. 127-142, 2004.

[33] G. Kim, B. Shin, and H. G. Lee, "Understanding dynamics between initial trust and usage intentions of mobile banking," Information Systems Journal, vol. 19, pp. 283-311, 2009.

[34] L. R. Vijayasarathy, "Predicting consumer intentions to use on-line shopping: The case for an augmented technology acceptance model," Information and Management, vol. 41, pp. 747-762, 2004.

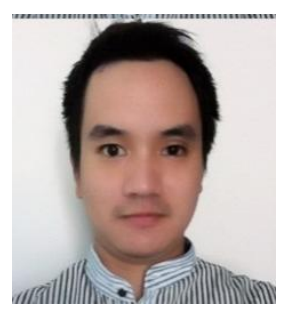

Chat Chuchuen was born at Sonkhla province, Thailand. $\mathrm{He}$ is a $\mathrm{PhD}$ candidate in Management Technology School Sirindhorn International Institute of Technology (SIIT), Thammasat University, Bangkok, Thailand. He earned his MSc. in information system management at School of Applied Statistics, National Institute of Development Administration (NIDA), Bangkok, Thailand in 2003 and his bachelor degree in business administration which major in computer business at Faculty of Management Science, Prince of Songkla university, Songkhla,Thailand in 2001.

$\mathrm{He}$ is currently a lecturer at Business Information System Program at Faculty of Business Adminisrtation, Maejo University, Chiang Mai, Thailand. His research areas are related with issues in mobile payment (M-payment), cloud computing, information systems adoption, customer relationship management (CRM), trust and security. 